\title{
THE USE OF ONLINE MEDIA AND TOPOGRAPHY MAP IN THE TOPIC OF LANDSLIDE NATURAL DISASTER, ADVANCED EARTH PHYSICS COURSE
}

\author{
Nur Islami \\ (nurislami@lecturer.unri.ac.id) \\ Physics Education, FKIP, Universitas Riau. Jl. HR. Soebrantas, Km. 12.5, \\ Pekanbaru, 28293, Indonesia
}

\begin{abstract}
Advanced Earth Physics course is one of the courses discusses all aspects of physics that exist in natural processes occurring on the earth. One of the topics discussed was Landslide Natural Disaster. The purpose of this study is to discuss the use of online media and topography map in Advance earth physics classes to analyse the location of possible landslides. This research was conducted on students who are taking advanced earth physics courses for the even semester in the University of Riau, Physics Education Study Program, and 20182019 academic year. Students were given the concept of a landslide and guidelines for using Google Earth and on how to produce the topography map. Then students were required to do a mini project in terms of using Google Earth and Topography Map and to analyse the possibility of a landslide zone. Subsequently, students were given a questionnaire about understanding the material of the Avalanche that was studied with the help of Google Earth and topography map. The results show that almost all students fully understand and like what they are doing, as evidenced by an average score of 3.78 (scale 4) in terms of Google Earth's utility in studying landslide zones. Thus it can be concluded that the Google Earth media is very well-liked and can provide a deeper understanding to students in learning the concept of Landslide Natural Disasters in Advanced Earth Physics courses.
\end{abstract}

Keywords: Google Earth, Landslide, Advanced Earth Physics.

\section{INTRODUCTION}

Advanced Earth Physics course is one of the elective courses given to students in the Physics Education Study Program, Universitas Riau, Indonesia. One of the topics discussed in this course is landslides natural disaster. Landslides are one of the natural disasters that often occur in Indonesia (Arifianti, 2011). Landslides can have a very large impact on the loss of lives (Rahman, 2015; Wang et al, 2014; Les et al, 2018). In landslides cases, many factors cause it. They are factors of soil conditions, slope gradient, rainfall and the trees that exist on the slopes of the land. To learn the concept 
of landslides, students need to be given the right media so that students understand the concept of landslides properly and correctly (Atsuhisa et al., 2019; Xiao et. 2018).

The use of media in learning is a very appropriate thing, whether it is real media, or media that is computer illustration or media using computers that are more contextual towards the learning material being carried out (Nada et al., 2012). A real media in question such as props, animations, videos and maybe even the spaciousness to see clearly what is being discussed in the learning. Gusmida and Islami (2017) have created a three-dimensional media by utilizing augmented reality to explain the concept of molecular movement in a container. Whereas Islami (2018) used Google Earth as a medium to increase understanding in studying tectonic plates. Arista et al (2018) used virtual laboratory applications to improve concept understanding in high school students. In his research, they found that an increase in student understanding after using this learning media. Kustijono et al (2019) found that Android-based interactive media can improve students' process abilities and thinking abilities. It appears that the ability of the process and thinking ability of students increases well.

Online media such as Google Earth have parts that are very useful in learning Earth Physics and in geography (Wayan, 2017). One of the items provided by Google Earth is a very accurate distance measurement, and can also produce coordinates and height of a place. In learning, Patterson (2007) has used Google Earth to provide students with an understanding of the state of the earth. Rifai (2017) also used Google Earth in studying geography to better introduce the earth to the students. Islami (2017) has tried to see how Google Earth analyzes the distance according to mathematical rules.

However, there has been no publication about the use of Google Earth to analyze avalanche in its learning. This research will discuss how to use Google Earth's online media in producing topographic maps so that it can be used in the study of Earth Physics, further on the subject of Landslide Disaster. This paper also discussed making mini-projects that must be done by each student to provide a deep understanding of this topic.

\section{METHODOLOGY}

In this study, the lecture and demonstration methods were used which were then ended with the method of giving a mini project to students. There were 34 students involved in this research, which were even semester of 2018-2019 students in the Physics Education Study Program, Universitas Riau. This research was directly related to the Advanced Earth Physics course which is a course at the Physics Education Program Study, Universitas Riau. 
The first procedure taken was to provide a basic concept of lecture material, namely Landslides Natural Disasters. In the lecture, this topic explains how landslides can occur, what losses can be caused by landslides, as well as how to identify the existing landslide zones based on parameters of physical meters that are obtained.

After giving the concept of landslide topics, then students were given a demonstration of the use of Google Earth media. At the end of the lecture, students are given a mini project about the detection of landslide zones with the help of Google Earth. In this mini-project, students were also asked to analyse it physically with the concepts given in the previous lecture.

After students submitted the mini-project assignments, at the next meeting students they are given the opportunity to explain their findings, but only 4 randomly selected students were asked to present this project. At the end of the meeting, students were given a questioner who later could provide information on how the role of the Google Earth media in the subject of the landslide natural disaster.

\section{RESULTS AND DISCUSSIONS}

\section{Understanding of the Concept of Landslides}

Figure 1 is one of the materials explained on the topic of landslides in this topic. Students were given a detailed explanation of the forces acting on the material so that the soil material is unstable and can cause landslides.
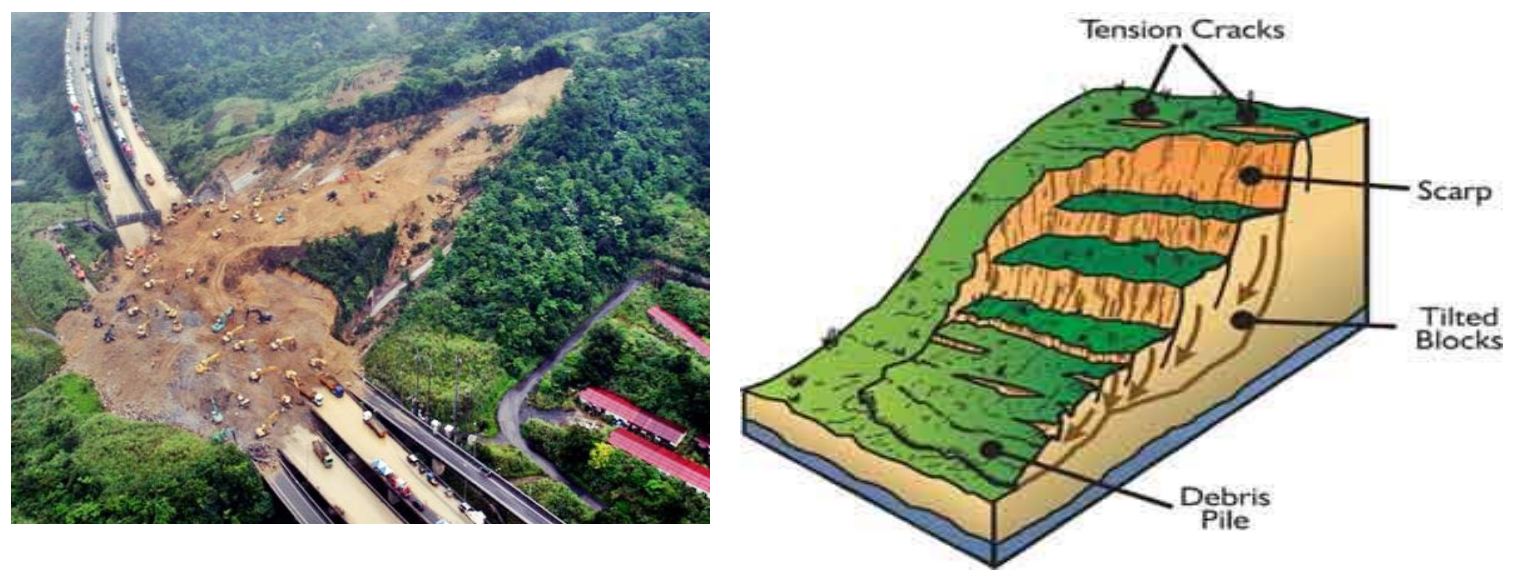

Figure 1. One of the landslides occurred (top) and a sketch of one type of ground movement (bottom). 
In Figure 1 (left) shows one of the land movement events resulting in property casualties and fatalities. Figure 1 (right) shows one of the types of ground movement made in sketch form.

\section{Introduction to Google Earth}

After explaining the concept of landslides to the students, the learning process continued by giving a demonstration about Google Earth. In this demonstration, the students were introduced to the tools available in Google Earth. Figure 2 is a display of Google Earth.

In figure 2, at the bottom we see the coordinates of the location where the cursor is placed, then the height of the view location where the cursor is placed and also the height of the eye position when the display is shown. These sections are very important as location navigation and also other physical parameters such as the direction of the compass.

\section{Topographic map of Google Earth}

After a demonstration of the use of the tools available in Google Earth, a demonstration of the shape of the earth's surface topography was focused on a hill at the edge of a village (Figure 3). From the results of this cross-section, it can be analysed the slope of the hill which is the main factor causing landslides in the hills. In Figure 3, the position of the village and the position of the cursor can be seen, so that it can be observed how close the housing in this village to the hills of the west of the village.

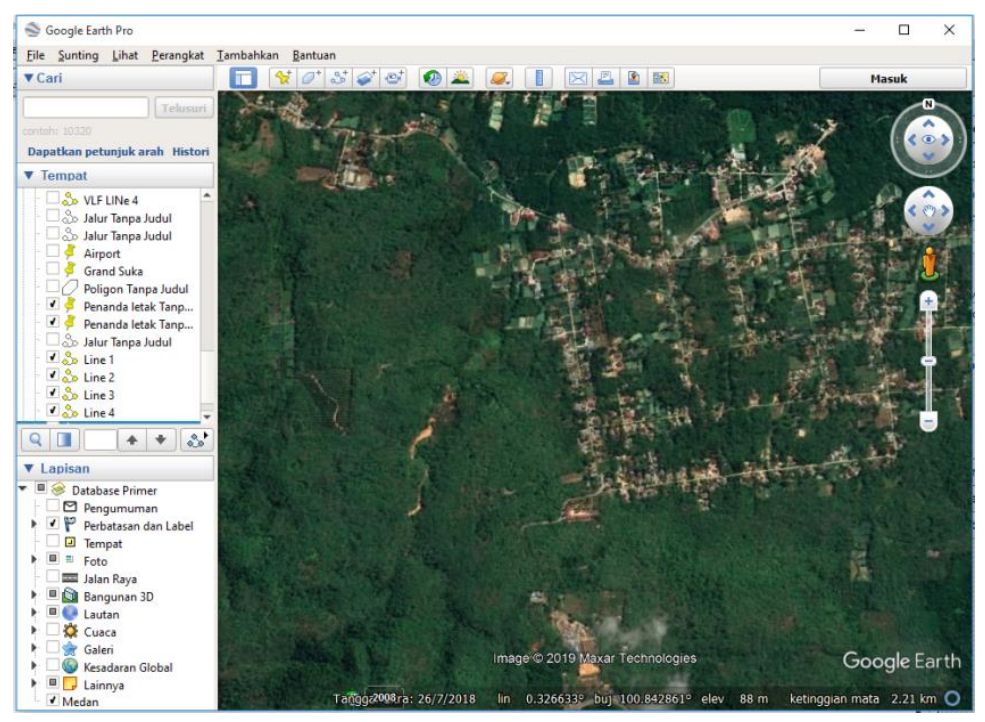

Figure 2. The illustration of the Google Earth 


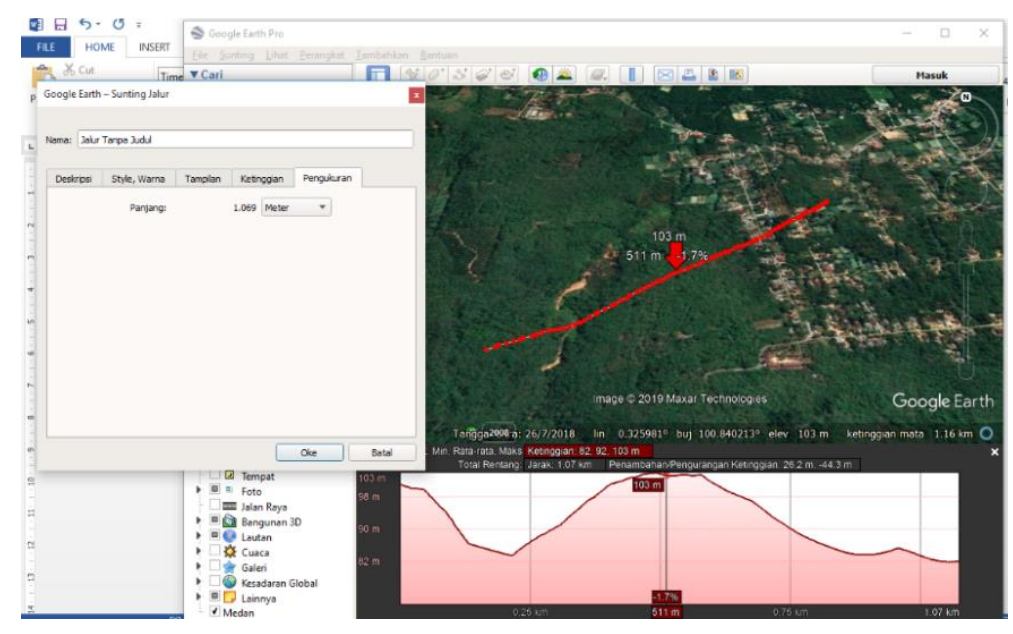

Figure 3. One of the tools in Google Earth.

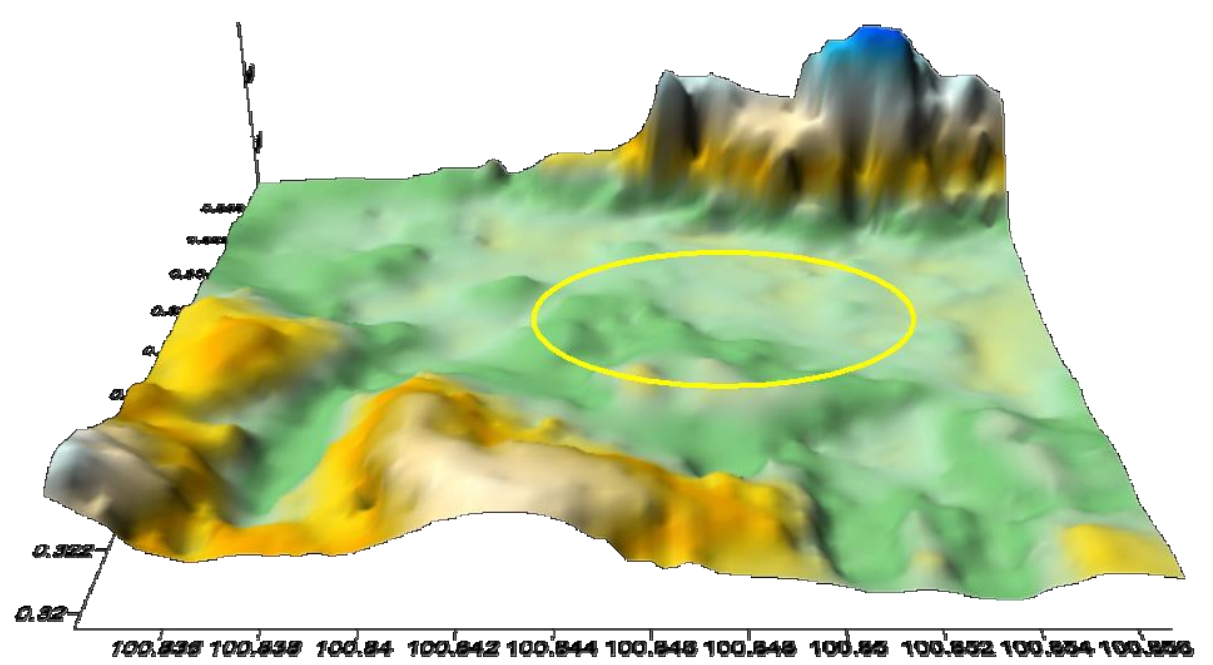

Figure 4. Topography map that can produce using Google Earth.

From the appearance of Google Earth, it can be converted into XYZ coordinates so that it can be mapped in the form of a three-dimensional map like in Figure 4. In this picture, the circular zone shows a village that previously appeared on Google Earth. In this 3D map, it can be seen the hills in the south and north are relatively close to the village. Students were required to analyse the slope of the hills and also analyse the possibility of whether or not there is a potential for landslides based on the slope and also in consideration of the friction coefficient between the particles making up the hill.

\section{Individual task}

After giving a demonstration about using Google Earth and converting it to a topographic map, students are required to do a mini project that is to analyse the whole possible landslide zone in a place. The parameters given were Longitude and Latitude coordinates for minimum positions, and longitude and Latitude coordinates for 
maximum positions. Besides that, the parameters given are the types of rocks that are in certain positions and also the frictional forces that exist for each particular type of rock. With the data provided, students were asked to produce an analysis which is confirming the possibility of the landslide.

\section{Individual Mini Project Results}

Figure 5 is one of the results of a mini-project created by one of the students. In this mini-project, students produced a map and a cross-section of the hill topography where there are residents housing. From the results obtained, the slope of hills 1 and 2 is obtained $32.16^{\circ}$ and $45.82^{\circ}$, respectively. The next analysis in figure 5 shows the description of the total force sketched on soil particles in the landslide zone. Based on the slope obtained, then the force produced that can cause soil movement, namely the component towards the slope. But some components resist the occurrence of soil movement. From this description, the students concluded that the slope 1 is still stable and safe.

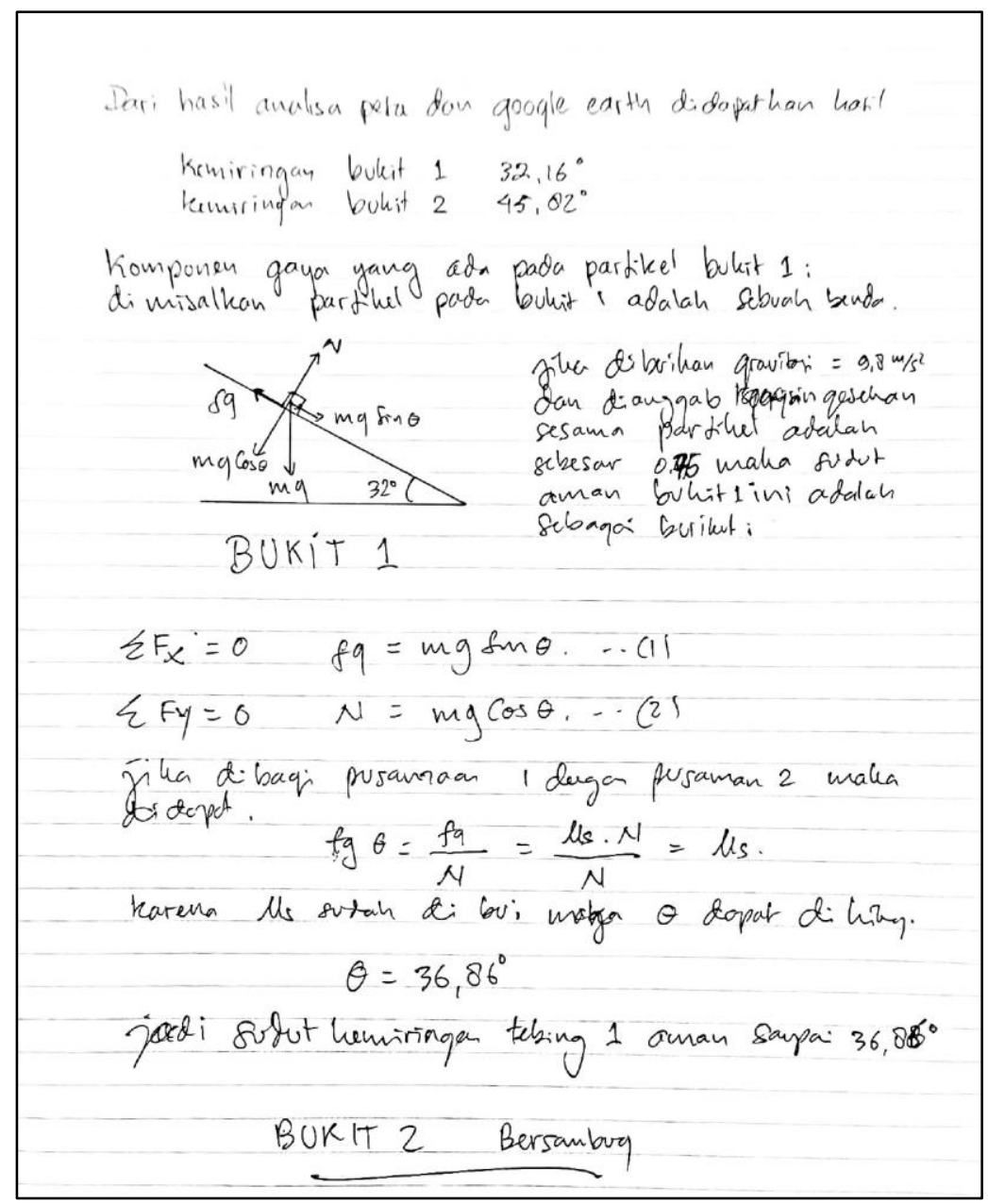

Figure 5. One of the results obtained from a student 
Table 1 is the result of calculations and analysis conducted by 38 students in working on a mini-project case study of a landslide analysis.

Table 1. The results of calculating the average slope of the hill

\begin{tabular}{|c|c|c|}
\hline Item & Average step & Std. Deviation \\
\hline The gradient of the hill 1 & $33.48^{0}$ & $2.65^{0}$ \\
\hline The gradient of the hill 2 & $45.75^{0}$ & $3.43^{0}$ \\
\hline $\begin{array}{l}\text { The maximum gradient of hill } 1 \text { with safe } \\
\text { conditions }\end{array}$ & $38.21^{0}$ & $6.11^{0}$ \\
\hline $\begin{array}{l}\text { The maximum gradient of hill } 2 \text { with safe } \\
\text { conditions }\end{array}$ & $58.12^{0}$ & $8.40^{\circ}$ \\
\hline
\end{tabular}

In table 1 it can be seen that the calculation of the gradient of the hill 1 and hill 2 , the answer of all the students are not too far away from each other. This can be seen from the standard deviations obtained, $2,65^{\circ}$ for hill 1 and $3,43^{\circ}$ for hill 2 . However, after all, calculations of other physical factors have been included and the decomposition of the force is taken into account, the standard deviation obtained has widened to more than $6^{0}$. This gives the sense that each interpretation of each student is somewhat different from each other. The different should be due to the interpretation of the forces working in each particle is different for one student and other.

\section{Questioner results}

Questioners given to students consisted of four questions that had to be answered on a scale of 1 to 4 . Answer for 1 was to indicate strongly disagree, and answer 4 was strongly agreed. Here are the questions are given in the questioner:

1. Can Google Earth media help in producing three-dimensional maps?

2. Can the map produce provide an understanding of the real situation where the hills are located?

3. Can calculations and analysis were done using Google Earth and topographic maps help produce good analysts?

4. Do you fully understand the concept of a Landslide Disaster?

Overall, students answered with a grade of 4 or 3 in their answers, so the average answer for all questions was 3.78. This grant provides information that Google Earth can assist in learning. This can be seen also from individual assignments done by students. Students understand how to produce projects and calculate the probability of landslides in a case study site. Thus the use of Google Earth online media, as well as topographic maps, has successfully provided students with a good understanding.

\section{CONCLUSION}

By using online media, such as Google Earth and topographic maps produced from Google Earth in the study of Advance Earth Physics, especially on the topic of 
Landslide Natural Disaster, the students have better understand into the analysis of the possibility of landslides well and meet the synthetic requirements in their analysis. Students can apply their scientific knowledge in doing existing calculations and analyses. In analysing, students apply several fields of science, including vector analysis, and mechanics derived from Newton's laws. Finally, students can understand the processes and conditions of landslides well and by linking them with their physical science.

\section{REFERENCES}

Arifianti, Y. (2011). Buku mengenal tanah longsor Sebagai media pembelajaran bencana sejak dini. - Bulletin Vulkanologi dan Bencana Geologi.

Arista, Fitra, S., Kuswanto, Heru. (2018). Virtual Physics Laboratory Application Based on the Android Smartphone to Improve Learning Independence and Conceptual Understanding. International Journal of Instruction, 11(1), 1-16.

Atsuhisa Y., Yoshinori S., Haruka T., Hideaki M., Tetsuya K. (2019). Distribution of landslides caused by heavy rainfall events and an earthquake in northern Aso Volcano, Japan from 1955 to 2016. Geomorphology, 327(15), 533-541

Gusmida, R., \& Islami, N. (2017). The Development of Learning Media for the Kinetic Theory of Gases Using the ADDIE Model with Augmented Reality. Journal of Educational Sciences, 1(1), 1-10

Islami N. (2017). Bagaimana Google Earth Mengukur Jarak. Jurnal Geliga Sains, 5 (1), $41-46$

Islami, N. (2018). The Use of Google Earth as the Learning Media in Geosciences Education. Journal of Educational Sciences, 2 (1), 56-63

Kustijono, R., Wiwin, E., \& Hakim, S.R. (2019). The effectiveness of android-based physics interactive media to train students' thinking and process skills, Journal of Physics: Conference Series 1171012026

Les B., Harley B., Ian L., Mike M., Stephen M.N., Mike P., \& Brenda R. (2018). A preliminary assessment of the impact of landslide, earthflow, and gully erosion on soil carbon stocks in New Zealand. Geomorphology, 307(15) 93-106

Nada, D. \& Anastasia, K. (2012). Personal Learning Environments, social media, and self-regulated learning: A natural formula for connecting formal and informal learning, The Internet and Higher Education, 15(1), 3-8, https://doi.org/10.1016/j.iheduc.2011.06.002

Patterson, T.C. (2007). Google Earth as a (Not Just) Geography Education Tool. Journal of Geography. 145-152. https://doi.org/10.1080/00221340701678032 
Rahman, A. (2015). Kajian Mitigasi Bencana Tanah Longsor Di Kabupaten Banjarnegara. Gema Publica : Jurnal Manajemen dan Kebijakan Publik, 1(1) 1-14, https://doi.org/10.14710/gp.1.1.2015.1-14

Rifai, M.H. (2017). Pemilihan Media Dalam Pembelajaran Geografi. Edudikara: Jurnal Pendidikan dan Pengajaran, 2(2), 34-42

Wang S.N., Shi C., Xu W., Zhang Y. \& Zhang, H. (2014). Estimation of Landslide Impact Disaster by Discrete Element Method: Jiangping Hydropower Station, Hubei, China. Landslide Science for a Safer Geoenvironment, 669-678

Xiao-li C., Chun-guo L., Ming-ming W., \& Qing Z. (2018) Causes of unusual distribution of coseismic landslides triggered by the Mw 6.1 2014 Ludian, Yunnan, China earthquake, Journal of Asian Earth Sciences, 159(15) 17-23 